\title{
Tingkat Pengetahuan Orang Tua terhadap Penyakit Pneumonia dan Imunisasi Pneumococcal Conjugate Vaccine (PCV) di Indonesia
}

\section{Parents' Knowledge Regarding Pneumonia and Pneumococcal Conjugate Vaccine (PCV) Immunization in Indonesia}

Erlika Saputri ${ }^{1}$, Dwi Endarti ${ }^{*}$, Tri Murti Andayani $^{3}$

1. Program Magister Manajemen Farmasi, Fakultas Farmasi, Universitas Gadjah Mada

2. Departemen Farmasetika, Fakultas Farmasi, Universitas Gadjah Mada

3. Departemen Farmakologi dan Farmasi Klinik, Fakultas Farmasi, Universitas Gadjah Mada

Submitted: 24-02-2020 Revised: 12-05-2020

Korespondensi : Dwi Endarti : Email : endarti_apt@ugm.ac.id

Accepted: 02-06-2020

\begin{abstract}
ABSTRAK
Imunisasi PCV terbukti efektif untuk mencegah pneumonia namun cakupan imunisasi tersebut masih rendah di Indonesia. Pengetahuan orang tua yang baik mengenai pneumonia dan vaksin PCV menjadi faktor penting dalam mendukung cakupan imunisasi PCV. Tujuan Penelitian adalah mengetahui tingkat pengetahuan orang tua tentang penyakit pneumonia dan imunisasi PCV serta mengetahui perbedaan nilai pengetahuan pada kelompok karakteristik sosiodemografi dan pengalaman responden. Rancangan penelitian yang digunakan yaitu obeservasional dengan pendekatan multi-center crosssectional. Data dikumpulkan melalui survei kepada responden orang tua di 5 provinsi di Indonesia yaitu di Provinsi DIY, Lampung, Sulawesi Tengah, Kalimantan Tengah, dan Jawa Barat dengan teknik convenience sampling. Instrumen penelitian menggunakan kuesioner untuk mengetahui karakteristik sosiodemografi dan tingkat pengetahuan. Analisis data dilakukan secara deksriptif dan statistik menggunakan uji Mann Whitney. Hasil penelitian menunjukkan bahwa dari 500 responden memiliki ratarata skor pengetahuan sebesar $80,6 \pm 12,8$ dan median 84,6 . Pengetahuan masih kurang pada item penyataan negatif yaitu imunisasi PCV termasuk dalam program jaminan kesehatan nasional di Indonesia dengan persentase responden yang menjawab benar 24,6\%. Terdapat perbedaan bermakna skor pengetahuan mengenai penyakit pneumonia dan imunisasi PCV antar kelompok pada karakteristik jumlah pengeluaran per bulan $(p=0,002)$, jumlah tanggungan $(p=0,002)$, pengalaman mendengar penyakit $(p=0,000)$, pengalaman terserang penyakit $(p=0,047)$, pengalaman mendengar vaksin $(p=0,000)$, dan sumber informasi vaksin $(p=0,024)$. Program edukasi kepada masyarakat Indonesia tentang penyakit pneumonia dan imunisasi PCV masih diperlukan agar pengetahuan menjadi tinggi.

Kata kunci: pengetahuan; pneumonia; vaksin PCV
\end{abstract}

\section{ABSTRACT}

PCV immunization has been proven to be effective in preventing pneumonia, but the immunization coverage is still low in Indonesia. Good parental knowledge about pneumonia and PCV vaccine is an important factor that can support the coverage of PCV immunization. The purpose of this study was to determine the level of parental knowledge about pneumonia and PCV immunization and to know the factors that influence it. This study observational design with a multi-center cross-sectional approach. Data was collected using survey to parents in 5 Provinces in Indonesia which were Provinces of DIY, Lampung, Sulawesi Tengah, Kalimantan Tengah, and Jawa Barat using convenience sampling. Study instrument consisted of questionnaire to determine sociodemographic characteristics and level of knowledge. Data was analyzed and presented descriptively and statistically using the Mann Whitney test. The results showed of 500 respondents had mean score of knowledge $80.6 \% \pm 12.8 \%$ and median of knowledge $84.6 \%$. Low knowledge was observed in the item of PCV immunization was not yet included in national program of immunization in Indonesia with percentage of respondents' correct answer was 24.6\%. There was significant difference in the score of knowledge about pneumonia and PCV immunization within different groups in the respondents' characteristics of expenditure per month $(p=0.001)$, number of responsibilities $(p=0.007)$, experience of hearing illness $(p=0,000)$, experience of illness $(p=0.046)$, experience of hearing vaccines $(p=0,000)$, and vaccine information sources $(p=0.024)$. 
Dwi Endarti, et al

This study suggests the need of regular education programs for community in Indonesia to improve knowledge regarding pneumonia and PCV immunization.

Keywords: knowledge; pneumonia; PCV vaccine

\section{PENDAHULUAN}

Pneumonia merupakan penyakit akibat infeksi bakteri Streptococcus pneumoniae atau pneumococcus yang dapat menyebabkan kematian terutama dinegara berkembang. ${ }^{1}$ Anak yang berusia $\leq 5$ tahun dan orang tua $\geq 65$ tahun lebih berisiko terinfeksi bakteri pneumococcus. ${ }^{2}$ Bakteri pneumococcus dapat menyebar melalui udara dari batuk atau bersin hingga saat seseorang berbicara atau melalui sentuhan dengan barang yang telah terkontaminasi oleh tetesan cairan dari orang yang terinfeksi. Orang yang mengalami pneumonia akan mengalami berbaga gejala meliputi demam, menggigil, kedinginan, batuk, sesak nafas serta nyeri dada. ${ }^{3}$ prevalensi pneumonia tahun 2018 adalah 4,0\% dengan prevalensi pneumonia tertinggi di Provinsi Papua dan Nusa Tenggara Timur. ${ }^{4}$

Salah satu untuk mencegah terjadinya penyakit pneumonia adalah penggunaan vaksin Pneumococcal Conjugate Vaccine (PCV) yang mampu memberikan perlindungan lebih tahan lama dan efektif pada anak-anak. ${ }^{5}$ World Health Organization (WHO) telah merekomendasikan penyertaan vaksin PCV dalam program imunisasi anak di seluruh dunia serta mengadakan program pengenalan vaksin PCV sebagai prioritas tinggi supaya penggunaan imunisasi PCV dapat secara rutin dilakukan. ${ }^{1}$ Program imunisasi PCV di Indonesia diberikan sebanyak 3 dosis yaitu pada bayi usia 2 bulan bersamaan DPT-HBHib 1 dan OPV 2, pada bayi usia 3 bulan bersamaan dengan DPT-HB-Hib 2 dan OPV 3, dan selanjutnya pada anak usia 12 bulan sebagai imunisasi lanjutan. ${ }^{6}$ Di Indonesia, kebijakan pemberian imunisasi PCV telah dikeluarkan oleh Kementerian Kesehatan yang dilaksanakan secara bertahap di dua kabupaten Provinsi Nusa Tenggara Barat yaitu Lombok Barat dan Lombok Timur mulai Oktober 2017.6 Bangka Belitung menjadi target kedua pelaksanaan imunisasi PCV setelah Nusa Tenggara Barat dan pelaksanaan demonstrasi imunisasi PCV dimulai pada akhir tahun 2018 dan awal tahun 2019 yang dilaksanakan di Provinsi Kepulauan Bangka Belitung pada kota Pangkal Pinang, Kabupaten Bangka, dan Kabupaten Bangka Tengah. Pada Oktober 2019 demonstrasi imunisasi PCV diperluas di Kabupaten Bangka Barat, Bangka Selatan, Belitung, dan Belitung Timur. ${ }^{7}$ Upaya ini diharapkan dapat meningkatkan cakupan imunisasi PCV karena penggunaan imunisasi PCV secara rutin dapat mengurangi kejadian pneumonia secara signifikan. ${ }^{1}$

Salah satu yang mempengaruhi cakupan imunisasi PCV adalah pengetahuan orang tua mengenai penyakit pneumonia dan imunisasi. Pengetahuan mempunyai peran penting dalam mendukung penggunaan imunisasi PCV rutin pada anak. Orang tua yang memiliki pengetahuan kurang terhadap manfaat dari pemberian imunisasi 5,51 kali berpeluang tidak menyelesaikan imunisasi anak dibandingkan dengan orang tua yang mengetahui manfaat imunisasi. ${ }^{8}$ Orang tua yang memiliki pengetahuan baik tentang manfaat imunisasi PCV dalam mencegah penyakit pneumonia berdampak poisitif bagi penggunaan imunisasi PCV. ${ }^{9}$ Pengetahuan orang tua mengenai imunisasi dipengaruhi oleh pendidikan, informasi yang diperoleh, sosial, budaya, dan ekonomi, lingkungan, dan pengalaman baik dari diri sendiri maupun orang lain. ${ }^{10}$ Pengetahuan orang tua dan tenaga kesehatan di Jawa Barat terkait imunisasi PCV masih rendah. ${ }^{11}$ Edukasi dari tenaga kesehatan merupakan upaya untuk meningkatkan pengetahuan masyarakat tetang pentingnya imunisasi sehingga dapat meningkatkan cakupan imunisasi. Penelitian ini melengkapi penelitian-penelitian sebelumny dengan jangkauan pengambilan sampel yang lebih luas meliputi 5 provinsi di Indonesia. Tujuan dari penelitian ini adalah mengetahui pengetahuan masyarakat Indonesia mengenai penyakit pneumonia dan imunisasi PCV serta mengetahui faktor yang dapat berpengaruh terhadap pengetahuan 
tersebut. Selain itu, hasil penelitian diharapkan dapat bermanfaat sebagai masukan bagi tenaga kesehatan untuk memberkan edukasi dalam upaya meningkatkan pengetahuan mengenai bahaya penyakit pneumonia dan manfaat imunisasi PCV yang bermanfaat bagi mereka.

\section{METODE}

\section{Desain Penelitian}

Penelitian ini menggunakan desain observasional dengan pendekatan multi-center cross sectional pada orang tua dan ibu hamil di 5 provinsi di Indonesia yaitu Provinsi DIY, Lampung, Sulawesi Tengah, Kalimantan Tengah dan Jawa Barat. Penelitian dilakukan di Puskesmas, PAUD, TK dan tempat pelaksanaan posyandu.

\section{Responden Penelitian}

Responden dipilih menggunakan teknik convenience sampling dengan kriteria inklusi yaitu orang tua yang memiliki anak dibawah 5 tahun dan ibu hamil yang tinggal dilokasi penelitian. Sedangkan kriteria eksklusinya yaitu orang tua dan ibu hamil yang tidak setuju untuk berpartisipasi dalam penelitian serta tidak mampu berkomunikasi dengan baik. Jumlah sampel ditentukan dengan menggunakan rumus Lemeshow dengan tingkat kepercayaan 95\% sehingga diperoleh jumlah sampel 100 responden untuk tiap provinsi dengan jumlah total responden yaitu 500 responden.

\section{Instrumen Penelitian}

Pengumpulan data dilakukan dengan menggunakan kuesioner yang dimodifikasi oleh peneliti dari beberapa literatur mengenai karakteristik sosiodemografi (usia, jenis kelamin, pendidikan, status pernikahan, status pekerjaan, pendapatan, pengeluaran, jumlah tanggungan, kepemilikan asuransi) dan pengalaman responden (pengalaman mendengar penyakit, pengalaman mendengar vaksin, pengalaman terserang penyakit, pengalaman divaksinasi, sumber informasi penyakit dan vaksin). Kuesioner pengetahuan responden mengenai penyakit pneumonia dan imunisasi PCV terdiri dari aspek etiologi, gejala, cara penularan, risiko, dampak penyakit, cara pencegahan penyakit, terapi, kegunaan vaksin, efek samping, dosis, kontraindikasi dan status vaksin dalam program imunisasi nasional.12,13,9 Validasi kuesioner dilakukan melalui uji content validity dengan melibatkan penilaian dari tiga ahli di bidang farmasi dan uji face validity kepada 10 responden non sampel.

\section{Analisis Data}

Jawaban pada kuesioner pengetahuan mengenai penyakit pneumonia dan imunisasi PCV yaitu dikotomis terdiri dari pilihan jawaban "Ya" dan "Tidak". Skor jawaban menggunakan skala Guttman yaitu "benar=1" dan "salah=0" pada pernyataan positif, sedangkan pada pernyataan negatif yaitu "benar=0" dan "salah=1". Nilai pengetahuan responden yang digunakan dihitung dengan rumus:

$$
x=\frac{a}{b} x 100
$$

Keterangan: $x=$ nilai pengetauan; $a=$ jumlah nilai yang menjawab dengan benar; $b=$ total nilai maksimal pengetahuan.

Analisis data dilakukan dengan analisis deskriptif dan statistik. Analisis deskriptif digunakan untuk mengetahui frekuensi serta persentase sosiodemografi, pengalaman, dan pengetahuan responden. Analisis statistik menggunakan uji beda Mann Whitney untuk mengetahui adanya perbedaan bermakna skor pengetahuan mengenai penyakit pneumonia dan imunisasi PCV pada kelompok karakteristik sosiodemografi dan pengalaman responden mengenai penyakit pneumonia dan imunisasi PCV dengan nilai $p<0,05$. Uji Mann Whitney digunakan karena data tidak terdistribusi normal.

\section{Persetujuan Etik}

Penelitian ini telah disetujui oleh komisi etik Fakultas Kedokteran, Kesehatan Masyarakat, dan Keperawatan Universitas Gadjah Mada dengan nomor KE/FK/1105/EC/2019. Responden sebelum mengisi kuesioner diberi informed consent sebagai persetujuan untuk berpartisipasi dalam penelitian. 
Tabel I. Gambaran Karakteristik Sosiodemografi Responden

\begin{tabular}{|c|c|c|}
\hline Karakteritik & $\begin{array}{l}\text { Jumlah Responden } \\
\quad(\mathrm{n}=500)\end{array}$ & $\begin{array}{l}\text { Persentase Jumlah } \\
\text { Responden (\%) }\end{array}$ \\
\hline Usia (Mean \pm SD) & $30,73 \pm 5,980$ & \\
\hline$\leq 25$ tahun & 60 & 12,0 \\
\hline$>25$ tahun & 440 & 88,0 \\
\hline \multicolumn{3}{|l|}{ Jenis Kelamin } \\
\hline Laki-laki & 147 & 29,4 \\
\hline Perempuan & 353 & 70,6 \\
\hline \multicolumn{3}{|l|}{ Pendidikan } \\
\hline Tidak sekolah, SD, SMP & 172 & 34,4 \\
\hline SMA, Perguruan Tinggi & 328 & 65,6 \\
\hline \multicolumn{3}{|l|}{ Status Pernikahan } \\
\hline Tidak Menikah & 11 & 2,2 \\
\hline Menikah & 489 & 97,8 \\
\hline \multicolumn{3}{|l|}{ Status Pekerjaan } \\
\hline Tidak bekerja & 127 & 25,4 \\
\hline Bekerja & 373 & 74,6 \\
\hline \multicolumn{3}{|l|}{ Jumlah Pendapatan /bulan } \\
\hline$<\operatorname{Rp} 2.218 .000$ & 261 & 52,2 \\
\hline$\geq \operatorname{Rp} 2.218 .000$ & 239 & 47,8 \\
\hline \multicolumn{3}{|l|}{ Jumlah Pengeluaran /bulan } \\
\hline$<\operatorname{Rp} 2.218 .000$ & 314 & 62,8 \\
\hline$\geq \operatorname{Rp} 2.218 .000$ & 186 & 37,2 \\
\hline \multicolumn{3}{|l|}{ Jumlah Tanggungan } \\
\hline$\leq 3$ orang & 333 & 66,6 \\
\hline$>3$ orang & 167 & 33,4 \\
\hline \multicolumn{3}{|l|}{ Kepemilikan Asuransi } \\
\hline Ya & 284 & 56,8 \\
\hline Tidak & 216 & 43,2 \\
\hline
\end{tabular}

\section{HASIL DAN PEMBAHASAN}

Karaketristik responden dari 500 responden pada 5 provinsi di Indonesia yaitu Provinsi DIY, Lampung, Sulawesi Tengah, Kalimantan Tengah dan Jawa Barat adalah (Tabel I).

Berdasarkan Tabel I, mayoritas karakteristik sosiodemografi responden yaitu usia $>25$ tahun $(88,0 \%)$ dengan pengelompokkan usia berdasarkan Depkes RI, 2009 , perempuan $(87,4 \%)$, pendidikan tinggi yaitu perguruan tinggi dan SMA (65,6\%), menikah (94,8\%), bekerja terdiri dari petani/pedagang/nelayan, buruh/pekerja part time, PNS/ TNI - Polri/ Pegawai BUMN,
Pegawai swasta, dan wiraswasta (74,6\%), jumlah pendapatan /bulan rendah yaitu $<\operatorname{Rp} 2.218 .000(52,2 \%)$, jumlah pengeluaran /bulan rendah yaitu $<\operatorname{Rp} 2.218 .000(62,8 \%)$, jumlah tanggungan $\leq 3$ orang $(66,6 \%)$, memiliki asuransi $(56,8 \%)$ (Tabel I).

Pengalaman responden mengenai penyakit pneumonia dan imunisasi PCV mayoritas tidak pernah mendengar penyakit pneumonia $(59,4 \%)$, anak/ lingkungan tidak pernah terserang penyakit pneumonia $(86,2 \%)$, tidak pernah mendengar imunisasi PCV (71,6\%), anak/ lingkungan tidak pernah melakukan imunisasi PCV (88,6\%), memperoleh informasi penyakit dari tenaga 
Tabel II. Gambaran Pengalaman Responden tentang Penyakit Pneumonia dan Imunisasi PCV

\begin{tabular}{lcc}
\hline Karakteritik & $\begin{array}{c}\text { Jumlah Responden } \\
(\mathbf{n}=\mathbf{5 0 0})\end{array}$ & $\begin{array}{c}\text { Persentase Jumlah } \\
\text { Responden (\%) }\end{array}$ \\
\hline Pengalaman Mendengar Penyakit & 203 & 40,6 \\
$\quad$ Ya & 297 & 59,4 \\
$\quad$ Tidak & & \\
Pengalaman Anak/ LingkunganTerserang Penyakit & 69 & 13,8 \\
$\quad$ Ya & 431 & 86,2 \\
$\quad$ Tidak & & \\
Pengalaman Mendengar Vaksin & 142 & 28,4 \\
$\quad$ Ya & 358 & 71,6 \\
$\quad$ Tidak & & 11,4 \\
Pengalaman Anak/ Lingkungan Pernah Vaksin & 57 & 88,6 \\
$\quad$ Ya & 443 & 26,8 \\
$\quad$ Tidak & & 13,8 \\
Sumber Informasi Penyakit & 134 & \\
$\quad$ Tenaga kesehatan, teman, anggota keluarga & 69 & 20,4 \\
$\quad$ Media massa dan lainnya & & 8,0 \\
Sumber Informasi Vaksin & 102 & \\
$\quad$ Tenaga kesehatan, teman, anggota keluarga & 40 & \\
$\quad$ Media massa dan lainnya & &
\end{tabular}

kesehatan, teman, anggota keluarga (26,8\%), dan informasi virus dari tenaga kesehatan, teman, anggota keluarga (20,4\%) (Tabel II).

Pengetahuan responden tentang penyakit pneumonia dan imunisasi PCV diukur dengan kuesioner berupa pernyataan positif dan negatif. Respon responden dengan memberikan pilihan ya atau tidak dari pernyataan tersebut. Persentase responden yang memberikan respon benar terhadap setiap pernyataan seperti pada tabel III.

Respon responden terhadap instrumen pengetahuan mengenai penyakit pneumonia dan imunisasi PCV pada Tabel III mayoritas menjawab pernyataan dengan benar sehingga pengetahuan masyarakat Indonesia mengenai penyakit pneumonia maupun imunisasi PCV baik, sedangkan pada penelitian lain menyatakan meskipun sebagian besar pengetahuan masyarakat mengenai pneumonia baik, tetapi pengetahuan mengenai imunisasi PCV masih rendah. ${ }^{11}$ Pengetahuan responden pada pernyataan negatif yaitu item imunisasi PCV masuk dalam program jaminan kesehatan nasional di
Indonesia, hanya $123(24,6 \%)$ responden yang mampu menjawab dengan benar sehingga mayoritas responden belum mengetahui bahwa imunisasi PCV adalah imunisasi yang dapat diperoleh masyarakat Indonesia dengan cara membayar sendiri. Edukasi dan konseling oleh tenaga kesehatan mengenai vaksin yang harus dibayar sendiri sangat diperlukan supaya mampu meningkatkan pengetahuan terhadap vaksin. ${ }^{14}$ Program intervensi pendidikan kesehatan sangat penting untuk mendidik dan meningkatkan pengetahuan serta memotivasi orang tua untuk mencegah dan mengendalikan penyakit. ${ }^{15}$ Rata-rata nilai responden sebesar $80,6 \pm 12,8$ yang diperoleh dari 13 pernyataan pengetahuan terkait penyakit pneumonia dan imunisasi PCV pada pernyataan positif maupun negatif dengan nilai 1 jika responden mampu menjawab dengan benar (Tabel IV).

Pengetahuan seseorang dapat dipengaruhi oleh pendidikan, informasi, sosial, budaya, dan ekonomi, lingkungan dan pengalaman. ${ }^{10}$ Penelitian lain juga menyatakan bahwa adanya hubungan 
Tabel III. Persentase Responden yang Menjawab Pernyataan Pengetahuan dengan Benar

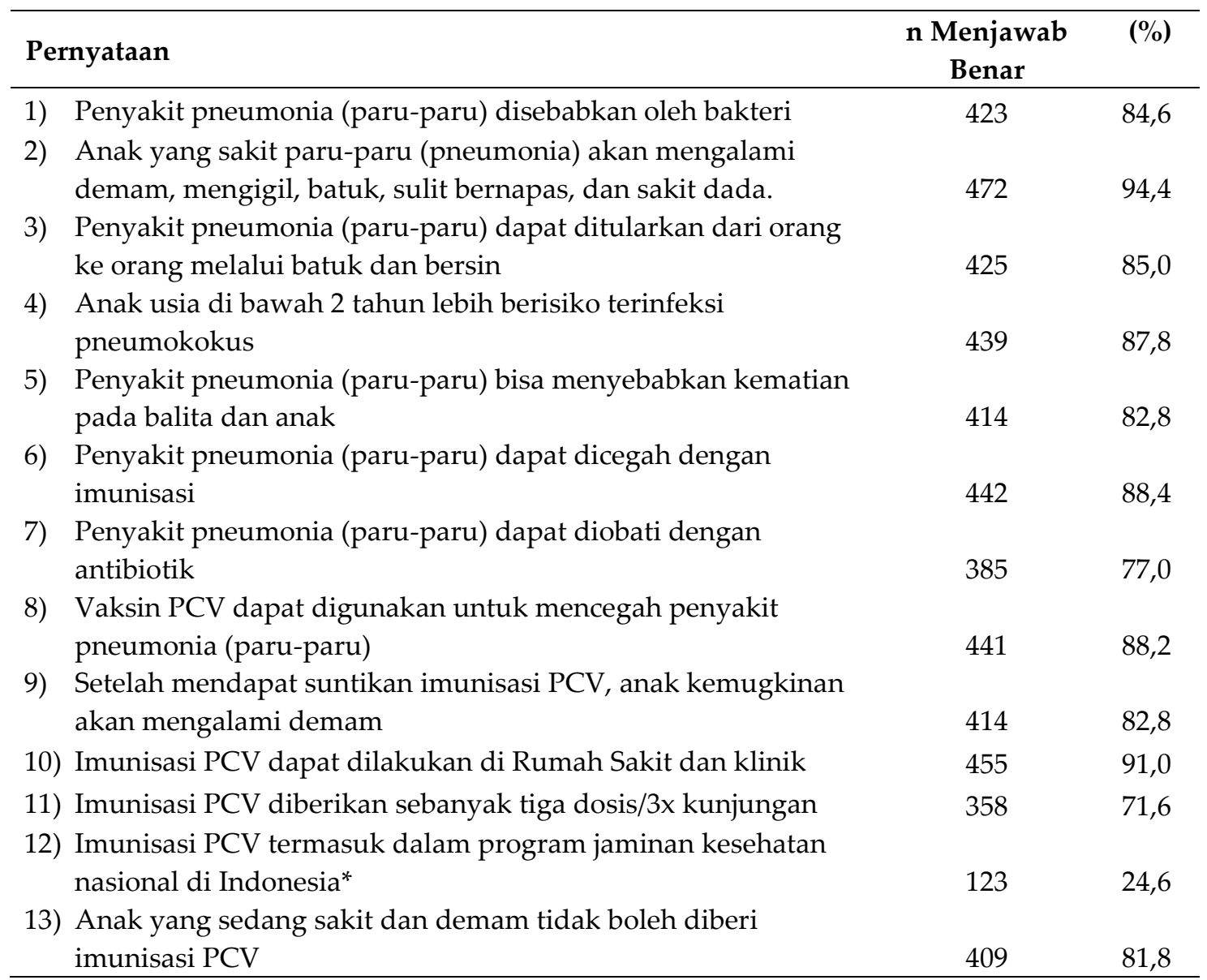

Keterangan: *Pernyataan negatif

signifikan pengetahuan mengenai penyakit dan imunisasi dengan beberapa faktor yaitu jenis kelamin, pendidikan, pekerjaan, dan pengeluaran per bulan, sedangkan umur dan jumlah tanggungan tidak memiliki pengaruh. ${ }^{15}$ Pada hasil uji Mann Whitney diketahui adanya perbedaan bermakna skor pengetahuan pada kelompok pengeluaran per bulan $(p=0,002)$ dan jumlah tanggungan $(p=0,002)$ (Tabel V). Orang tua yang memiliki jumlah pengeluaran /bulan yang tinggi memungkinkan orang tua tersebut menggunakan uangnya untuk memperoleh akses ke pelayanan kesehatan dan lebih sering berinteraksi dengan tenaga kesehatan sehingga memperoleh informasi mengenai penyakit dan imunisasi dengan baik. ${ }^{15}$ Orang tua yang memiliki jumlah tanggungan $\leq 3$ orang memiliki nilai pengetahuan yang lebih tinggi dibandingkan orang tua yang memiliki jumlah tanggungan $>3$ orang. Hasil ini berbeda dengan hasil penelitian lain yang menyatakan tidak ada perbedaan skor pengetahuan mengenai imunisasi antara orang tua yang memiliki anak dengan jumlah kecil maupun besar sehingga mereka samasama memiliki pengetahuan yang baik mengenai imunisasi. ${ }^{15,16}$

Pada penelitian ini, skor pengetahuan mengenai penyakit pneumonia dan imunisasi PCV tidak memiliki perbedaan bermakna pada usia, jenis kelamin, pendidikan, status pernikahan, pekerjaan, pendapatan per bulan, dan kepemilikan asuransi dengan nilai $\mathrm{p} \geq 0,05$ (Tabel V). Status pernikahan tidak mempengaruhi perbedaan nilai pengetahuan karena baik orang tua yang menikah atau tidak, memiliki pengetahuan yang baik akan 
Tabel IV. Pengetahuan Responden tentang Penyakit Pneumonia dan Vaksin PCV

\begin{tabular}{lc}
\hline & Nilai Pengetahuan* \\
\hline Rata-rata \pm SD & $80,6 \pm 12,8$ \\
Median & 84,6 \\
Minimum & 30,8 \\
Maksimum & 100,0 \\
\hline
\end{tabular}

Keterangan: *Nilai pengetahuan memiliki skor 0 - 100

Tabel V. Perbedaan Pengetahuan Responden Berdasarkan Karakteristik Sosiodemografi

\begin{tabular}{|c|c|c|c|}
\hline Karakteristik $(n=500)$ & Median & Rata-rata & pvalue \\
\hline \multicolumn{4}{|l|}{ Usia } \\
\hline$<25$ tahun & 84,62 & 80,13 & \multirow{2}{*}{0,633} \\
\hline$\geq 25$ tahun & 84,62 & 80,72 & \\
\hline \multicolumn{4}{|l|}{ Jenis Kelamin } \\
\hline Laki-laki & 84,62 & 80,43 & \multirow{2}{*}{0,812} \\
\hline Perempuan & 84,62 & 80,74 & \\
\hline \multicolumn{4}{|l|}{ Pendidikan } \\
\hline Tidak Sekolah, SD, SMP & 84,62 & 79,92 & \multirow{2}{*}{0,214} \\
\hline SMA, Perguruan Tinggi & 84,62 & 81,03 & \\
\hline \multicolumn{4}{|l|}{ Status Pernikahan } \\
\hline Tidak Menikah & 92,31 & 83,92 & \multirow{2}{*}{0,365} \\
\hline Menikah & 84,62 & 80,57 & \\
\hline \multicolumn{4}{|l|}{ Status Pekerjaan } \\
\hline Tidak Bekerja & 84,62 & 81,65 & \multirow{2}{*}{0,308} \\
\hline Bekerja & 84,62 & 80,31 & \\
\hline \multicolumn{4}{|l|}{ Pendapatan } \\
\hline$<\operatorname{Rp} 2.218 .000$ & 84,62 & 80,08 & \multirow{2}{*}{0,128} \\
\hline$\geq \operatorname{Rp} 2.218 .000$ & 84,62 & 81,27 & \\
\hline \multicolumn{4}{|l|}{ Pengeluaran } \\
\hline$<\operatorname{Rp} 2.218 .000$ & 84,62 & 79,57 & \multirow{2}{*}{$0,002^{*}$} \\
\hline$\geq \operatorname{Rp} 2.218 .000$ & 84,62 & 82,46 & \\
\hline \multicolumn{4}{|l|}{ Jumlah Tanggungan } \\
\hline$\leq 3$ orang & 84,62 & 81,68 & \multirow{2}{*}{$0,002^{*}$} \\
\hline$>3$ orang & 76,92 & 78,58 & \\
\hline \multicolumn{4}{|l|}{ Kepemilikan Asuransi } \\
\hline $\mathrm{Ya}$ & 84,62 & 80,72 & \multirow{2}{*}{0,986} \\
\hline Tidak & 84,62 & 80,56 & \\
\hline
\end{tabular}

Keterangan: * Hasil uji Mann-Whitney pada taraf kepercayaan 95\% menunjukkan perbedaan yang signifikan

penyakit imunisasi. ${ }^{17}$ Perbedaan nilai pengetahuan tidak terdapat pada pendapatan per bulan karena informasi mengenai pneumonia dan imunisasi PCV dapat diperoleh tidak hanya dari pelayanan kesehatan tetapi dari teman, keluarga maupun media massa sehingga baik orang tua yang memiliki pendapatan rendah maupun tinggi mampu memperoleh informasi secara gratis sehingga mampu memiliki pengetahuan yang baik terhadap bahaya penyakit pneumonia dan pentingnya imunisasi PCV. 
Penelitian lain menyebutkan bahwa pengetahuan dipengaruhi oleh usia, jenis kelamin, tingkat pendidikan, dan pekerjaan. Usia memiliki peran penting dalam pemanfaatan layanan kesehatan dan memiliki pengaruh positif pada penerimaan vaksin karena ibu yang lebih tua memiliki banyak pengetahuan tentang layanan kesehatan dan menilai imunisasi itu penting bagi anak mereka. ${ }^{17}$ Namun pada hasil penelitian ini, usia tidak mempengaruhi perbedaan pengetahuan mengenai penyakit pneumonia dan imunisasi PCV sehingga baik orang tua yang lebih tua atau muda memiliki pengetahuan yang baik. ${ }^{15} \mathrm{Hal}$ ini dikarenakan dengan berkembangnya teknologi maka informasi mengenai penyakit dan imunisasi dapat diperoleh dengan mudah oleh semua usia sehingga dapat meningkatkan pengetahuan tentang penyakit dan imunisasi dengan baik. Perempuan akan lebih memiliki pengetahuan yang tinggi mengenai penyakit pneumonia dan imunisasi PCV dibandingkan laki-laki karena ibu lebih sering mengasuh dan menemani anak mereka ke posyandu sehingga lebih cenderung mengetahui tentang penyakit dan vaksin. ${ }^{15}$ Orang tua yang memiliki pendidikan rendah memiliki kurangnya kesadaran akan imunisasi anak mereka dibandingkan orang tua yang memiliki pendidikan tinggi. ${ }^{19}$ Kurangnya pendidikan dapat menyebabkan berkurangnya kemampuan seseorang untuk menemukan, memahami dan menggunakan informasi kesehatan sehingga pendidikan menjadi faktor penentu akan pentingnya status kesehatan bagi mereka. ${ }^{20}$ Orang tua yang tidak bekerja memiliki pengetahuan yang lebih baik mengenai penyakit dan imunisasi karena mereka memiliki banyak waktu menemani anak untuk berkunjung ke pelayanan kesehatan sehingga lebih sering mendapatkan edukasi dari tenaga kesehatan mengenai penyakit dan imunisasi. ${ }^{15}$ Namun pada penelitian ini hubungan signifikan antara skor pengetahuan dengan faktor sosiodemografi tersebut tidak ditemukan.

Skor pengetahuan responden juga dianalisis hubungannya dengan pengalaman mengenai penyakit pneumonia dan imunisasi PCV. Pada hasil uji Mann Whitney, diketahui bahwa skor pengetahuan mengenai penyakit pneumonia dan imunisasi PCV memiliki perbedaan bermakna pada kelompak pengalaman pengalaman mendengar penyakit $(\mathrm{p}=0,000)$ dan pengalaman mendengar vaksin $(p=0,000)$ (Tabel VI). Orang tua yang pernah mendengar mengenai penyakit pneumonia dan vaksin PCV memiliki nilai pengetahuan yang lebih tinggi dibandingkan yang belum pernah mendengar. Hal ini dikarenakan dengan adanya informasi yang diperoleh seseorang baik dari tenaga kesehatan, teman, keluarga, dan media massa mampu meningkatkan pemahaman mereka mengenai suatu penyakit maupun vaksin sehingga mampu menghasilkan perubahan serta meningkatkan pengetahuan.10 Skor pengetahuan memiliki perbedaan bermakna pada pengalaman anak terserang penyakit $(p=0,047)$. Orang tua yang memiliki anak pernah terserang penyakit pneumonia akan memiliki pengetahuan yang lebih baik dibandingkan orang tua yang memiliki anak belum pernah terserang penyakit karena pengalaman yang dialami anak mereka akan menjadi pengetahuan bagi orang tua mengenai penyakit, bahaya dan dampak penyakit tersebut. ${ }^{10}$

Perbedaan bermakna skor pengetahuan juga terdapat pada sumber informasi vaksin $(p=0,024) \quad$ (Tabel VI). Orang tua yang mendapatkan sumber informasi vaksin dari tenaga kesehatan, teman dan anggota keluarga memiliki nilai pengetahuan lebih tinggi dibandingkan sumber informasi dari media massa dan lainnya. Hal ini sesuai dengan hasil penelitian lain yang menyatakan bahwa sumber informasi dari tenaga kesehatan adalah sumber informasi yang paling terpercaya dan memiliki pengaruh positif mengenai vaksinasi. ${ }^{22}$ Faktor yang paling sering mempengaruhi keputusan orang tua mengenai imunisasi pada anak mereka yaitu saran dari dokter. ${ }^{23}$ Selain tenaga kesehatan, keluarga dan teman menjadi faktor sosial yang mampu mempengaruhi pengetahuan seseorang mengenai penyakit 
Tabel VI. Perbedaan Pengetahuan Responden Terhadap Pengalaman mengenai Penyakit Pneumonia dan Imunisasi PCV

\begin{tabular}{lccc}
\hline Karakteristik $(\mathbf{n}=\mathbf{5 0 0})$ & Median & Mean & p value \\
\hline Pernah Mendengar Penyakit Pneumonia & & & \\
$\quad$ Ya & 84,62 & 84,16 & $0,000^{*}$ \\
$\quad$ Tidak & 84,62 & 78,24 & \\
Anak Pernah Terserang Penyakit Pneumonia & & & \\
$\quad$ Ya & 84,62 & 83,95 & $0,047^{*}$ \\
$\quad$ Tidak & 84,62 & 80,12 & \\
Pernah Mendengar Vaksin PCV & & & \\
$\quad$ Ya & 92,31 & 84,07 & $0,000^{*}$ \\
$\quad$ Tidak & 84,62 & 79,29 & \\
Anak Pernah di Vaksin PCV & & & \\
$\quad$ Ya & 84,62 & 81,38 & 0,685 \\
$\quad$ Tidak & 84,62 & 80,55 & \\
Sumber Informasi Penyakit Pneumonia & & & \\
$\quad$ Tenaga kesehatan, teman, anggota keluarga & 84,62 & 82,84 & 0,241 \\
$\quad$ Media massa dan lainnya & 84,62 & 81,27 & \\
Sumber Informasi Vaksin PCV & & & \\
$\quad$ Tenaga kesehatan, teman, anggota keluarga & 92,31 & 83,33 & $0,024^{*}$ \\
$\quad$ Media massa dan lainnya & 84,62 & 79,88 & \\
\hline
\end{tabular}

Keterangan: * Hasil uji Mann-Whitney pada taraf kepercayaan 95\% menunjukkan perbedaan yang signifikan

pneumonia dan vaksinasi PCV karena pendapat mereka mudah untuk diterima. ${ }^{12}$ Skor pengetahuan tidak memiliki perbedaan bermakna pada pengalaman anak terserang penyakit, pengalaman pernah divaksin, dan sumber informasi penyakit dengan nilai $p>0,05$ (Tabel VI). Namun penelitian lain menyatakan bahwa orang yang memiliki pengalaman mengenai penyakit atau imunisasi maka akan memiliki pengetahuan yang baik akan hal tersebut. ${ }^{10}$

\section{KESIMPULAN}

Pengetahuan masyarakat Indonesia mengenai penyakit pneumonia dan imunisasi PCV baik karena mayoritas mampu menjawab pernyataan terkait pengetahuan dengan benar, namun mayoritas responden menjawab dengan salah pada item imunisasi PCV termasuk program imunisasi anak nasional. Skor pengetahuan pada kelompok pengeluaran per bulan, jumlah tanggungan, pengalaman mendengar penyakit, pengalaman anak terserang penyakit, pengalaman mendengar vaksin, dan sumber informasi vaksin memiliki perbedaan bermakna.

\section{UCAPAN TERIMAKASIH}

Penelitian ini merupakan bagian dari penelitian tesis Erlika Saputri pada Program Studi Magister Ilmu Farmasi Minat Manajemen Farmasi UGM. Penulis mengucapkan terima kasih kepada Fakultas Farmasi atas bantuan dana untuk penelitian ini melalui Hibah Penelitian Fakultas Farmasi UGM Tahun 2019.

\section{DAFTAR PUSTAKA}

1. WHO. Pneumococcal Disease. World Health Organization. Published September 29, 2014. Accessed April 18, 2019.

https:/www.who.int/immunization/dis eases/pneumococcal/en/

2. WHO. Introduction of Pneumococcal 
Vaccine PCV13, A Handbook for District and Health Facility Staff. World Health Organization; 2013.

3. CDC. Pneumococcal Disease. Centers for Disease Control and Prevention. Published September 6, 2017. Accessed July 11, 2019. https://www.cdc.gov/pneumococcal/ab out/index.html

4. Kemenkes RI. Hasil Utama Riset Kesehatan Dasar 2018. Badan Penelitian dan Pengembangan Kesehatan; 2018.

5. Isaacs A. Immunization in practice, a practical guide for health staff. Arch Dis Child. 2005;90(9):988-988.

6. Kemenkes RI. Imunisasi Dicanangkan di Lombok. Biro Komunikasi dan Pelayanan Masyarakat. Oktober 2017:1.

7. Chandralela A. Wagub: Lindungi Anak Babel dari Pneumonia dengan Imunisasi PCV. Dinas Komunikasi dan Informatika.

https://babelprov.go.id/content/wagublindungi-anak-babel-dari-pneumoniadengan-imunisasi-pcv. Published September 16, 2019. Accessed May 5, 2020.

8. Suryawati I, Abdullah A. Cakupan Imunisasi Dasar Anak Ditinjau Dari Pendekatan Health Belief Model Immunization Coverage in Children Based on Health Belief Model. 2016;4(1):12.

9. How $\mathrm{CH}$, Phua See Chun P, Shafi F, Jakes RW. Parental knowledge, attitudes and perception of pneumococcal disease and pneumococcal conjugate vaccines in Singapore: a questionnaire-based assessment. BMC Public Health. 2016;16(1):923.

10. Budiman, Riyanto A. Kapita Selekta Kuesioner: Pengetahuan dan Sikap dalam Penelitian Kesehatan. Salemba Medika; 2013.

11. Harjaningrum AT, Kartasasmita C, Orne-Gliemann J, Jutand M-A, Goujon $\mathrm{N}$, Koeck J-L. A qualitative study on knowledge, perceptions, and attitudes of mothers and health care providers toward pneumococcal conjugate vaccine in Bandung, West Java, Indonesia. Vaccine. 2013;31(11):15161522.

12. Chan YY, Ibrahim MA bin, Wagle AA, Wong CM, Chow A. A formative research-guided educational intervention to improve the knowledge and attitudes of seniors towards influenza and pneumococcal vaccinations. Vaccine. 2017;35(47):63676374.

13. Loubet $\mathrm{P}$, Kernéis $\mathrm{S}$, Groh $\mathrm{M}$, et al. Attitude, knowledge and factors associated with influenza and pneumococcal vaccine uptake in a large cohort of patients with secondary immune deficiency. Vaccine. 2015;33(31):3703-3708.

14. Hou Z, Jie Chang null, Yue D, Fang $H$, Meng Q, Zhang Y. Determinants of willingness to pay for self-paid vaccines in China. Vaccine. 2014;32(35):4471-4477.

15. Wahed T, Kaukab SST, Saha NC, et al. Knowledge of, attitudes toward, and preventive practices relating to cholera and oral cholera vaccine among urban high-risk groups: findings of a crosssectional study in Dhaka, Bangladesh. BMC Public Health. 2013;13(1):242.

16. Alharthi K, Mahfouz ME, Althobaiti K, Alharthi A, Alzahrani A. Knowledge, Attitude towards vaccination among parents, Saudi Arabia. Int J Sci Eng Res. 2017;8(12):1834-1839.

17. Abdulraheem I, Onajole A, Jimoh A, Oladipo AR. Reasons for incomplete vaccination and factors for missed opportunities among rural Nigerian children. J Public Health Epidemiol. 2011;3(4):194-203.

18. Negussie A, Kassahun W, Assegid S, Hagan AK. Factors associated with incomplete childhood immunization in Arbegona district, southern Ethiopia: a case - control study. BMC Public Health. 
2016;16(27).

19. Mugada V, Chandrabhotia S, Divya S, Kaja S. Knowledge towards Childhood Immunization among Mothers and Reasons for Incomplete Immunization. J Appl Pharm Sci. 2017;7(10):157-161.

20. Ramadan H, Soliman S, El-kader R. Knowledge, Attitude and Practice of Mothers toward Children's Obligatory Vaccination. IOSR J Nurs Health Sci. 2016;05:22-28.

21. Yousif M, Albarraq AA, Abdallah MAA, Elbur AI. Parents' Knowledge and Attitudes on Childhood Immunization, Taif, Saudi Arabia. J Vaccines Vaccin. 2014;05(01):1-5.

22. Deleanu D, Petricau C, Leru P, et al. Knowledge Influences Attitudes toward Vaccination in Romania. Exp Ther Med. 2019;18(6):5088-5094.

23. Coniglio MA, Platania M, Privitera D, Giammanco G, Pignato S. Parents' attitudes and behaviours towards recommended vaccinations in Sicily, Italy. BMC Public Health. 2011;11(1):305. 